\title{
EVALUATING THE ECOPHYSIOLOGY OF SURVIVAL FOR MAPANIA CUSPIDATA (MIQ.) UITTIEN (CYPERACEAE) TRANSPLANTATION
}

\author{
Received July 19, 2021; accepted December 14, 2021
}

\author{
ZINNIRAH SHABDIN \\ Faculty of Resource Science and Technology, Universiti Malaysia Sarawak, 94300 Kota Samarahan, Sarawak. \\ Email: szinnirah@unimas.my
}

\section{HOLLENA NORI}

Faculty of Resource Science and Technology, Universiti Malaysia Sarawak, 94300 Kota Samarahan, Sarawak. Email:nhollena@unimas.my

\section{MEEKIONG KALU}

Faculty of Resource Science and Technology, Universiti Malaysia Sarawak, 94300 Kota Samarahan, Sarawak. Email:aqmuzzammil@unimas.my

\section{MOHAMMAD FAJARUDDIN MOHD FAIZ}

Faculty of Resource Science and Technology, Universiti Malaysia Sarawak, 94300 Kota Samarahan, Sarawak. Email: fajarfariz18@gmail.com

\begin{abstract}
SHABDIN, Z., NORI, H., MEEKIONG, K. \& FAIZ, M. F. M. 2021. Evaluating the ecophysiology of survival for Mapania cuspidata (Miq.) Uittien (Cyperaceae) transplantation. Reinwardtia 20(2): 69-75. - This study aimed to investigate the ecology of the sedge Mapania cuspidata at three different locations in East Malaysia, namely Gunung Gading, Matang and Bengoh, and the survival of M. cuspidata transplanted in pots exposed to different light intensities in Universiti Malaysia Sarawak, East Malaysia. The highest species density was recorded in Matang with a total density of 1.98 individuals/ha followed by Bengoh (1.42) and Gunung Gading (0.96). In these locations, the soil pH ranged from 4.9 in Bengoh to 5.7 in Matang where as soil organic matter content was between $3.47 \%$ in Bengoh and $8.68 \%$ in Gunung Gading. The highest light intensity was recorded in Matang with 0.94 kLux, and produced plants with the highest chorophyll content (64.8 SPAD value). This study found that the transplanted M. cuspidata had $90 \%$ survival over a four month experiment, produced $\sim 8$ new leaves, took an average of 15.8 days to produce a new leaf and had a chlorophyll content of $\sim 30.3$ SPAD value regardless of the intensity of light where the plants were exposed to. The findings of this study suggests that M. cuspidata can grow well in any light conditions and therefore it is also possible to transplant and re-establish other Mapania species in new location. It is hoped that the initiative to relocate other Mapania species of concervation concern will be effective if adequate post-harvest handling methods are practiced.
\end{abstract}

Key words: Ecophysiology, light intensity, Mapania, vegetative propagation.

\begin{abstract}
ABSTRAK
SHABDIN, Z., NORI, H., MEEKIONG, K. \& FAIZ, M. F. M. 2021. Evaluasi ekofisiologi ketahanan transplantasi Mapania cuspidata (Miq.) Uittien (Cyperaceae). Reinwardtia 20(2): 69-75. - Tujuan penelitian ini adalah untuk mengkaji faktor-faktor ekologi jenis tersebut di tiga lokasi di Malaysia Timur, yaitu Gunung Gading, Matang dan Bengoh, serta menganalisis kemampuan bertahan hidup M. cuspidata yang ditanam di dalam pot terbuka yang terpapar sinar matahari dengan intensitas cahaya yang berbeda-beda di Universiti Malaysia Sarawak, Malaysia Timur. Kerapatan jenis tertinggi tercatat di Matang dengan jumlah 1,98 individu/ha, diikuti Bengoh $(1,42)$ dan Gunung Gading $(0,96)$. $\mathrm{pH}$ tanah di lokasi tersebut berkisar dari 4,9 di Bengoh hingga 5,7 di Matang, dengan kandungan tanah organik berkisar antara 3,47\% di Bengoh dan 8,68\% di Gunung Gading. Intensitas cahaya tertinggi tercatat di Matang dengan 0,94 kLux, dan menghasilkan tumbuhan dengan kandungan klorofil tertinggi (nilai SPAD 64,8). Penelitian ini menunjukkan bahwa $M$. cuspidata yang ditanam dalam pot setelah melalui durasi pertumbuhan selama empat bulan mempunyai kemampuan bertahan hidup sebesar $90 \%$, menghasilkan 8 daun baru, dan membutuhkan waktu rata-rata 15,8 hari untuk menghasilkan daun baru serta mempunyai kandungan klorofil dengan nilai SPAD 30,3 terlepas dari intensitas cahaya di mana tanaman terpapar. Penelitian ini menunjukkan bahwa M. cuspidata dapat tumbuh dengan baik dalam semua kondisi cahaya, oleh sebab itu memungkinkan untuk penanaman dan menanam kembali jenis Mapania lainnya di lokasi baru. Diharapkan inisiatif untuk merelokasi jenis Mapania lain yang menjadi perhatian konservasi akan efektif jika dilakukan metode penanganan pasca panen yang memadai.
\end{abstract}

Kata kunci: Ekofisiologi, intensitas cahaya, Mapania, perbanyakan vegetatif. 


\section{INTRODUCTION}

Cyperaceae (sedges) is a monocotyledonous angiosperm plant family with over 5387 species (Govaerts et al., 2007). They are of economic, ethnobotanical, conservation and environmental importance. Their economic importance has often been underestimated due to their local and regional use (Simpson \& Inglis, 2001). Since early Egyptian civilization, sedges have been recognized, particularly through the role of papyrus (Cyperus papyrus), in providing writing and cons truction materials. Their importance has since wide-ranging, from the trouble they cause as weeds (e.g. Cyperus rotundus L.), to the substantial number of uses such as providing materials for basketry, matting, construction, perfumery, medicine and fuel, as well as food and animal fodder (Negbi, 1992; Govaerts et al., 2007, Simpson \& Inglis, 2001). They also serve as dominant components of many wetland ecosystems and are reliable indicators of habitat degradation in such systems (Simpson et al., 2003), consequently acting as environmental indicators for conservation. They also play a vital role in preventing erosion and flooding in many ecosystems (Naczi \& Ford, 2008). This family currently includes two subfamilies, Mapanioideae and Cyperoideae (Govaerts et al., 2007; Muasya et al., 2009), with genus Mapania being under subfamily Mapanioideae. The diversity of Mapania species from Sarawak is tremendous, with 31 out of 71 world's total number are recorded (Miraadila et al., 2016). Studies on Mapania of Sarawak since 2008 by Shabdin et al. (2013a, 2013b, 2016) has observed the high tendency of endemicity of the species to Borneo (M. longiflora, M. angustifolia, M. lorea, M. debilis, M. maschalina, M. obscuriflora, M. richardsii, $M$. borneensis, $M$. latifolia and $M$. hispida), and hyper-endemicity (M. foxworthyi, $M$. graminea, M. sapuaniana and M. multiflora). Only a few species are widespread; for instance, M. cuspidata. This species is well-distributed in South-East Asia, including Thailand, Peninsular Malaysia, Singapore, Sumatra, Java, Borneo, Brunei Darussalam, Philippines, Maluku, Papua, Sulawesi, Papua New Guinea, Solomon Islands and New Hebrides. In Sarawak, this species may occur in mixed dipterocarp, kerangas, swamp, limestone and degraded forests. Mapania is locally known as rumput serapat or pandan tikus by the Malay people. In Sarawak, Mapania is also called as daun meing by the Iban, tenduh in Bidayuh language, daon sisiet by Melanau, ieee in Saban and Kelabit language, and da'aah in Kenyah and Penan dialectal (Miraadila, 2018). Although many Cyperaceae members are heliophytes adapted to open environment, this does not apply to members of Mapania which prefers growing on the ground layer of tropical rainforests in low light conditions (Simpson, 1992). According to Engelbrecht et al. (2007), drought has a limiting effect on the tropical plant distributions and observed that global warming in tropical rainforests could result in loss of diversity and species extinction. Drier conditions could, therefore, accelerate the decline, and extinction of many Mapania species throughout the tropics (Simpson et al., 2011). Other factors such as dispersal ability of the species and niche suitability certainly play parts in the survival of Mapania spp. However, how well Mapania could migrate with changing climate or adapt to new conditions is unknown.

Most Mapania species occur in an uncommon habitat of Cyperaceae, which prefer open areas with direct sunlight (Miraadila, 2018). Members of this genus occur where little light penetrates through the canopy, and usually in areas where the soil is damp, muddy, or peaty, or in swampy depressions or by the side of pools or streams (Simpson, 1992). Some species occur in a very restricted habitat, resulting in a high number of endemic species. $M$. sapuaniana for example, has so far only been recorded in a small area at Sungai Joh (approx. $3 \mathrm{~km}$ radius) of Lanjak Entimau Wildlife Sanctuary (LEWS) (Shabdin et al., 2016), while M. ballehensis, M. kipas and M. mirae are recorded only from Baleh National Park. In many field expeditions conducted since 2008, the effort of collecting living specimens to be planted in our arboretum has failed, although the collection includes preserving some soil of the species original habitat. We have been attempting to plant several species of conservation concern, such as M. kadimiana which was found only in Sarikei to this date, but unable to survive in its transplanted habitat. Another notable attempt at transplanting involved the vulnerable species $M$. multiflora, which was discovered in 2008 in Limbang. This species has not been found in Sarawak since the site of its discovery was cleared for development in 2010 . Should we understand the physiology or translocation management of the species, we might have been able to transplant this species to a new habitat for its conservation. As ex situ transplanted for Mapania species are difficult to be done due to sensitivity of the plants to a new environment and incapable to uphold the water in evaporation from the root system, this paper aims to understand how environmental factors affect the distribution of 


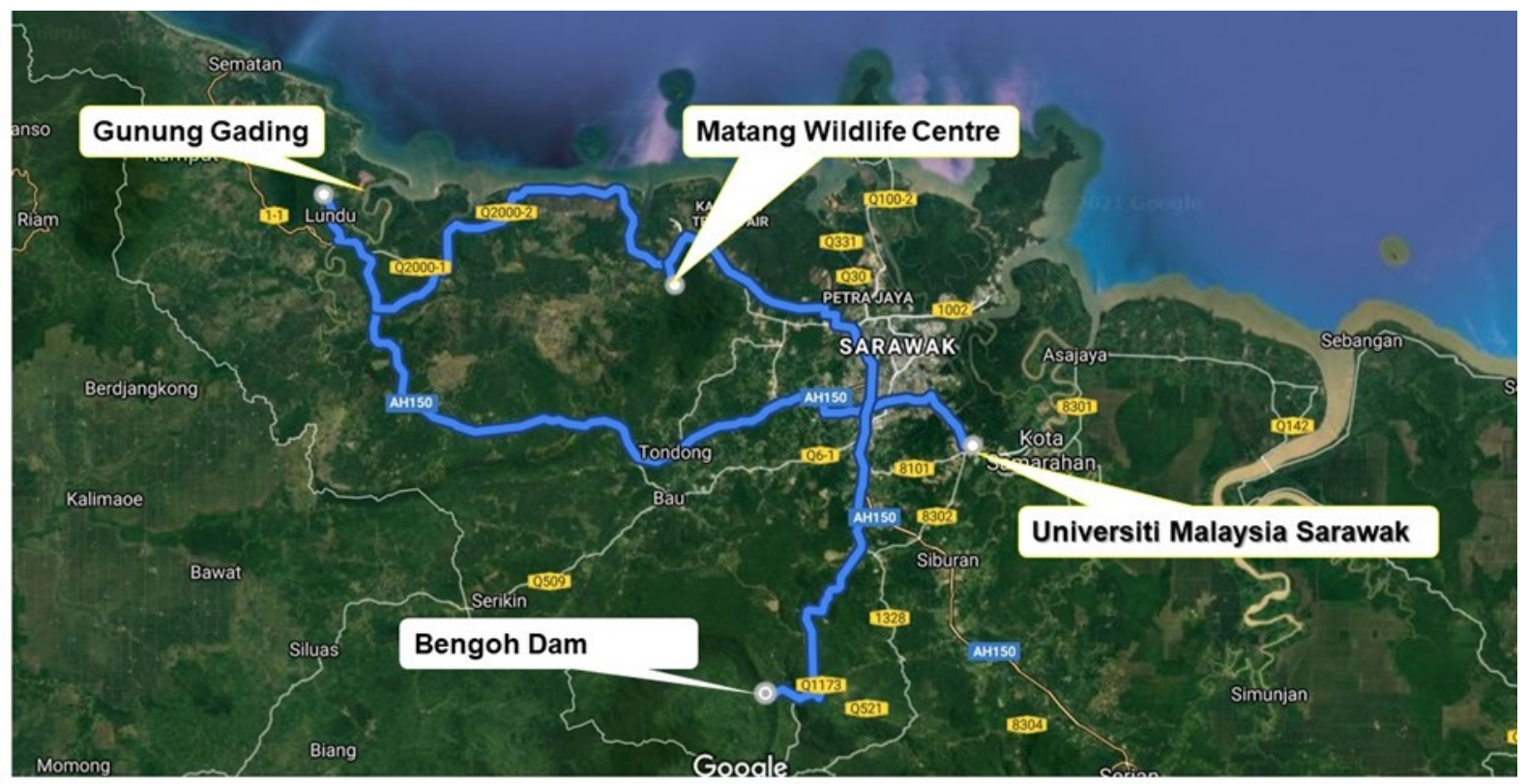

Fig. 1. The locations of Matang, Gunung Gading and Bengoh where Mapania cuspidata inhabits. (Source: Google Map).

Mapania cuspidata in different natural habitats and then quantify key ecophysiology metrics of this species concerning survival, growth and development following attempt in transplanting at a new location.

\section{MATERIALS AND METHODS}

\section{Observational field study}

Three locations in Sarawak, Malaysia were selected for this study, namely Matang ( $1^{\circ} 37^{\prime} 52.4^{\prime \prime} \mathrm{N}$, $\left.110^{\circ} 08^{\prime} 11.3^{\prime \prime} \mathrm{E}\right)$, Gunung Gading $\left(1^{\circ} 41^{\prime} 29.15^{\prime \prime} \mathrm{N}\right.$, $\left.109^{\circ} 50^{\prime} 46.33^{\prime \prime} \mathrm{E}\right)$ and Bengoh $\left(1^{\circ} 18^{\prime} 24.4^{\prime \prime} \mathrm{N}, 110^{\circ}\right.$ 13'09.3"E) (Fig. 1). These three locations were selected due to accessibility and the presence of $M$. cuspidata. In each location, the sampling was conducted in five random plots with each plot measuring $250 \mathrm{~m}^{2}$. Within each plot, 10 quadrates of $25 \mathrm{~m}^{2}$ were randomly placed to quantify plant populations, chlorophyll content, soil $\mathrm{pH}$ and organic matter content. Non-destructive approach was used to count plant populations and a chlorophyll meter (SPAD-502Plus, Konica, Minolta) was used to measure the plant chlorophyll content. Soil samples were collected at 0-200 $\mathrm{mm}$ depth using a soil auger. The soil samples were then sent to the laboratory for chemical analysis. Soil $\mathrm{pH}$ was measured using a $\mathrm{pH}$ meter whereas soil organic matter was measured using Loss on Ignition (LoI) method (Ball, 1964). For light intensity, five readings were taken from each plot using a handheld light meter (Extech EA30, Massachusetts, U.S.).

\section{Transplantation experiment}

A total of 36 healthy and disease-free individuals were collected from the Matang habitat for a transplantation experiment on survival and growth in Universiti Malaysia Sarawak. Plants from Matang were selected because of it was the nearest location to Universiti Malaysia Sarawak (approximately a two hour drive) and thereby reduced the lag time of plant recovery due to injury and stress. At the sampling location, the soil around the plants was explored to determine the extent of feeding roots prior to lifting. Using a hand shovel, the plants were dug with a mass of soil around the roots while keeping as much of the root ball intact as possible. The sampling was done early in the morning and the plants were selected with no particular age consideration. All leaves were removed during the transportation process, to reduce the water stress due to evaporation. Upon arrival at the destination, the plants were placed in plastic buckets filled with $1.5 \mathrm{~L}$ tap water to keep the roots moistened and stored in an unlit, airconditioned laboratory at $25^{\circ} \mathrm{C}$ for five days to restore the plant vigor. This was also intended to simulate the natural living conditions of $M$. cuspidata as this species were found living in damp and 
wet areas near to the rivers and streams with moist and wet soil conditions (Miraadila et al., 2015). Then, the plants in the buckets were placed in a corridor outside the laboratory (sheltered condition) for another five days to acclimatize before transplanting into polybags measuring $254 \times 305$ $\mathrm{mm}$. These polybags were filled with potting mix containing a mixture of coco peat, burnt soil, river sand, burnt husk, rich humus and charcoal powder (Kean Beng Lee Industries (M) Sdn. Bhd.).

The transplantation experiment comprised of four light intensities, i.e. 7, 18, 54 and $100 \%$ with nine replicates each. To do this, three mini-green houses were built with different shading netting percentage (1 layer created 54\%, 2 layers created $18 \%$ and 3 layers created $7 \%$ light intensity). For $100 \%$ light intensity, the plants in polybags were exposed under full sunlight. The relative light intensity was obtained by comparison of light readings taken inside and outside of the minigreen house. No fertilizer and pesticide were applied during the experiment. Any fungus or weed growth were removed manually and polybags were watered daily to ensure the soil remained moist. The plants were left to grow for a period of 130 days with observations taken at weekly intervals, starting at 30 days from the date of transplanting. Four ecophysiology parameters were measured, i.e. final number of leaves, leaf production rate, chlorophyll content and survival rate of each treatment. The leaf production rate was calculated from the regression of the leaf number against accumulated days. The chlorophyll content was measured using a chlorophyll meter (SPAD-502Plus, Konica, Minolta). Plant survival rate was calculated by dividing the number of survived plants in the end of the experiment against total number of transplanted plants at the beginning of the experiment.

\section{Data analysis}

Statistical analysis used VassarStat (http:// vassarstats.net/) (Richard Lowry, 1998-2021). All variables were analyzed using analysis of variance (ANOVA) and treatment means were compared by Tukey's Honest Significant Test (HSD) using an alpha value of $\mathrm{P}<0.05$ for establishing statistical significance. Pooled standard errors of the mean were reported for each measured variable.

\section{RESULTS}

The density of $M$. cuspidata was highest at Matang with total density of 1.98 individuals/ha compared to Bengoh (1.42) while Gunung Gading showed the lowest density of 0.96 . However, statistical analysis showed no significant difference in the populations of $M$. cuspidata per $250 \mathrm{~m}^{2}$ among these three locations (Table 1). Matang recorded the highest light intensity of 0.94 kLux on the forest floor, whereas both Gunung Gading and Bengoh had an average of $\sim 0.34 \mathrm{kLux}$. Plants in Matang also had the greatest chlorophyll content (67.4 SPAD unit) compared with those in Gunung Gading and Bengoh ( 56.2 SPAD unit). In terms of soil parameters, the $\mathrm{pH}$ and organic matter content varied among the locations (Table 1). The soil in all locations was found to be acidic with the lowest $\mathrm{pH}$ recorded in Bengoh ( $\mathrm{pH} 4.9)$ followed by Gunung Gading ( $\mathrm{pH}$ 5.5) and Matang $(\mathrm{pH}$ 5.7). The soil organic matter ranged from $3.47 \%$ in Bengoh to $8.68 \%$ in Gunung Gading.

Observation after 130 days from transplanting found that there was no significant difference in the ecophysiology of $M$. cuspidata with an average survival rate of $88.9 \%$ across all light treatment (Table 2). In addition, the plants successfully produced an average of $\sim 7.7$ new leaves throughout the growing period with $\sim 15.8$ days interval to produce each succesive leaf. These new, developing leaves had an average chlorophyll content of $\sim 30.3$ SPAD unit across all light conditions. In contrast, plants in the natural habitats despite living under low illumination had a higher chlorophyll content (52.6-67.4 SPAD unit) (Table 1) because the leaves had fully developed and matured. Lower chlorophyll content in the new, young leaves was expected because the leaves have not attained their maximum size and therefore were unable to maximize photosynthetic activity.

\section{DISCUSSION}

Observation of $M$. cuspidata in its natural habitat found that the population densities of the species were similar across all locations in Gunung Gading, Matang and Bengoh with an average density of 14.4 individuals per $250 \mathrm{~m}^{2}$ area. The results from statistical analysis showed that presence of $M$. cuspidata was not affected by the differences in light intensity $(0.32-0.94 \mathrm{kLux})$ and soil chemical properties ( $\mathrm{pH}$ 4.9-5.7, organic matter 3.47-8.68\%) (Table 1). This observation is consistent with the generalized expectation that most Mapania species are found in shaded areas with water-logging soil conditions or near bodies of water (Simpson, 1992). Despite variation in light intensity among the locations, the highest illuminance of $0.94 \mathrm{kLux}$ on the forest floor is 
Table 1. Plant populations, chorophyll content, light intensity and soil parameters in Gunung Gading, Matang and Bengoh where Mapania cuspidata (Miq.) Uittien were observed.

\begin{tabular}{lccccc}
\hline Location & $\begin{array}{c}\text { M. cuspidata popula- } \\
\text { tions } / 250 \mathrm{~m}^{2}\end{array}$ & $\begin{array}{c}\text { Light inten- } \\
\text { sity (kLux) }\end{array}$ & $\begin{array}{c}\text { Chlorophyll } \\
\text { content (SPAD } \\
\text { unit) }\end{array}$ & \multicolumn{2}{c}{ Soil parameters } \\
\hline $\begin{array}{l}\text { Gunung Gad- } \\
\text { ing }\end{array}$ & 9.2 & $0.32^{\mathrm{b}}$ & $59.8^{\mathrm{b}}$ & $5.5^{\mathrm{a}}$ & $\begin{array}{c}\text { Organic } \\
\text { matter (\%) }\end{array}$ \\
Matang & 19.8 & $0.94^{\mathrm{a}}$ & $67.4^{\mathrm{a}}$ & $5.7^{\mathrm{b}}$ & $5.77^{\mathrm{b}}$ \\
Bengoh & 14.2 & $0.35^{\mathrm{b}}$ & $52.6^{\mathrm{b}}$ & $4.9^{\mathrm{c}}$ & $3.47^{\mathrm{c}}$ \\
\hline \multicolumn{1}{c}{ S.E.M } & 1.90 & 0.078 & 2.03 & 0.15 & 0.953 \\
\multicolumn{1}{c}{ P-value } & $0.062(\mathrm{~ns})$ & $<0.001$ & $<0.001$ & $<0.001$ & $<0.001$ \\
\hline
\end{tabular}

S.E.M., Standard Error of Means; ns, P $>0.05$. Means with the same letters are not significantly different $(\mathrm{P}>0.05)$ based on Tukey's HSD test.

Table 2. Survival, leaf production rate, number of leaves and chlorophyll content of Mapania cuspidata (Miq.) Uittien grown under different levels of light intensity in Universiti Malaysia Sarawak, East Malaysia.

\begin{tabular}{ccccc}
\hline $\begin{array}{c}\text { Relative light } \\
\text { intensity (\%) }\end{array}$ & \multicolumn{4}{c}{ Ecophysiology parameters } \\
\cline { 2 - 5 } & Survival $^{1}(\%)$ & $\begin{array}{c}\text { Leaf production rate } \\
\text { (days/leaf) }\end{array}$ & $\begin{array}{c}\text { Number of } \\
\text { leaves }\end{array}$ & $\begin{array}{c}{ }^{1} \\
\text { Chlorophyll content } \\
\text { (SPAD unit) }\end{array}$ \\
\hline 7 & 77.8 & 14.4 & 8.2 & 31.9 \\
18 & 88.9 & 16.0 & 8.2 & 32.8 \\
54 & 100.0 & 16.2 & 7.2 & 26.6 \\
100 & 88.9 & 16.5 & 7.3 & 29.7 \\
\hline S.E.M. & 5.31 & 0.80 & 0.41 & 1.95 \\
P-value & $0.553(\mathrm{~ns})$ & $0.818(\mathrm{~ns})$ & $0.754(\mathrm{~ns})$ & 0.707 (ns) \\
\hline
\end{tabular}

${ }^{1}$ Survival, final number of leaves and chlorophyll content were measured after 130 days from transplanting. S.E.M., Standard Error of Means; ns, P $>0.05$.

equivalent to an overcast weather in an open area and therefore is considered as conditions of low brightness. This study suggests that $M$. cuspidata can thrive in conditions of acidic soil with significant amount of organic matter. Associated with this is the need to identify other Mapania species that may inhabit the same ecological niche with $M$. cuspidata in future work.

The results of transplantation experiment have shown successful establishment of $M$. cuspidata under shaded and open area conditions with an average survival rate of $89 \%$ (Table 2). During the course of 130 days post-transplanting, M. cuspidata developed an average of 7.7 new leaves with leaf production rate of 15.8 days/leaf. The findings of this study are substantial yet confounding given extensive reviews on Mapania species being shade loving plants that grow well in conditions of damp and wet soils (Simpson, 1992; Shabdin et al., 2013a, 2013b; Miraadila et al., 2016a) and failing attempts to plant the species in new locations (Z. Shabdin, pers. comm.). Following successful pot transplantation experiment, the individuals of $M$. cuspidata were relocated to the arboretum of Universiti Malaysia Sarawak and observation two years later found these plants remain thriving the new environment (Fig. 2). These new findings on high survival of M. cuspidata in the transplantation study implies that there is a good chance to plant other Mapania species that are of a greater conservation concern in new locations. 

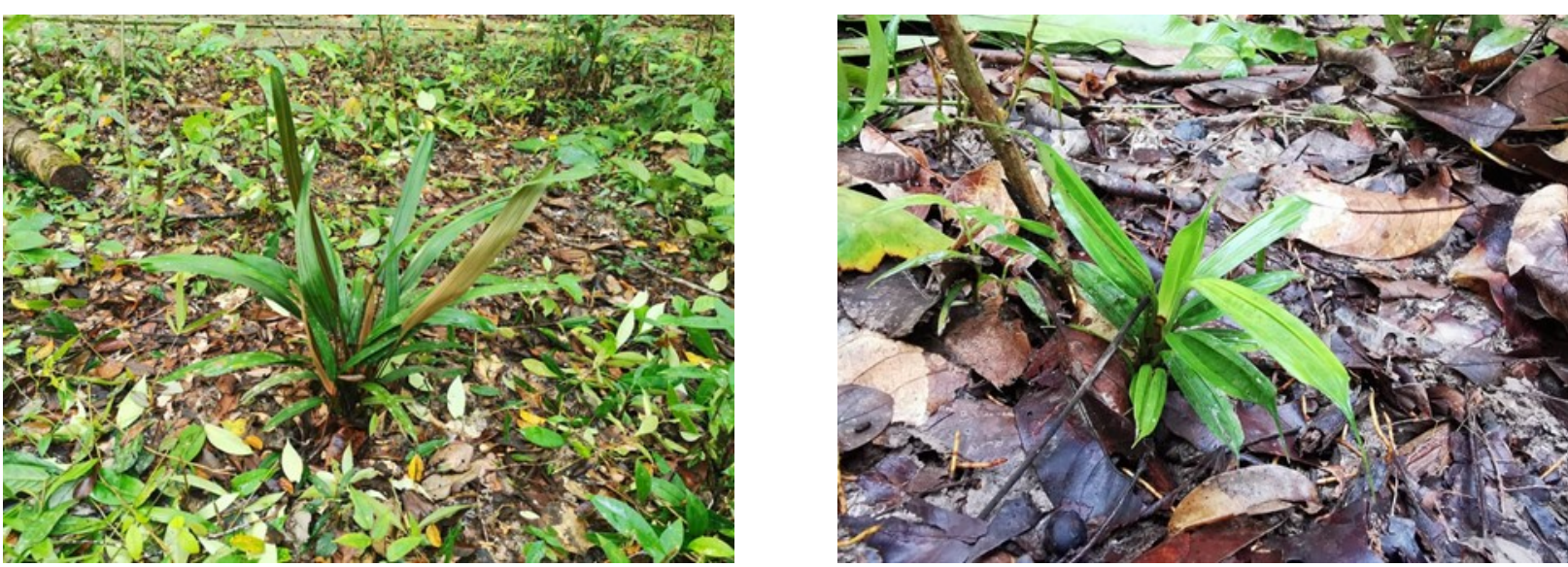

Fig. 2. Mature (left) and juvenile (right) Mapania cuspidata successfully established in the arboretum of Universiti Malaysia Sarawak two years after the pot transplanting experiment.

Nevertheless, the success in transplantation and growing M. cuspidata in different environments was likely aided by careful considerations of the impact of lifting, transporting and pretransplanting during the process of plant relocation. Careful lifting of plants from the ground is critical because the roots need to be protected during handling. This is because the survival and performance of any transplanted plant is largely dependent on the ability of roots to develop and recover from injury and stress (Jackson et al., 2012). Equally, the conditions of transport and storage determine the survival rate and quality of plants after transplanting. Water stress during transport or storage of plants can delay root regeneration and subsequent growth following transplanting, while worst case scenario could result in high mortality rate (Apostol et al., 2009). Therefore, transit time, temperature, moisture and duration of storage are important parameters that need to be optimized (Goyette et al., 2014). Additionally, plants should be acclimatized to prepare them for survival under higher temperatures and levels of irradiance. Transplanting should be carried out under ideal conditions, i.e. late afternoon or overcast weather to allow the plants to recover from transplanting injury while avoiding midday heat and being subjected to less evaporation of water. Finally, the plants should be transplanted to the same depth in its new location. This can be done by examining the soil mark on the stem. Specifically for endemic plant species, factors concerning the plant life form, physical size, distribution range, population size and whether the relocation site is within the species historical range must be taken into account first before making decision to transplant for the purpose of ex situ conservation (Liu et al., 2015). This is because endemic species have specific habitat conditions which require stable and constant environment, making them more vulnerable than other plant species to natural changes. Due to its potential ecological risks, conservation transplantation of endemic species to new location should be within the historical range area and would require careful management and longer post planting monitoring. In short, the survival and success in establishment of transplanted plant are greatly dependent on the decisions and post harvest handling practices. With adequate knowledge and understanding on plant ecophysiology and post harvest management, it is possible to relocate and establish plant species in new locations for ex situ conservation and to increase its widespread distribution.

\section{ACKNOWLEDGEMENTS}

We wish to express our gratitude to Universiti Malaysia Sarawak (UNIMAS) for the facilities, also to to our support staffs for their assistance with the fieldwork.

\section{REFERENCES}

APOSTOL, K. G., JACOBS, D. F. \& DUMROESE, R. K. 2009. Root desiccation and drought stress response of bareroot Quercus rubra seedlings treated with a hydrophilic polymer root dip. Plant Soil 315: 229-240.

BALL, D. F. 1964. Loss-on-ignition as an estimate of organic matter and organic carbon in noncalcareous soils. Journal of Soil Science 15: 8492. 
ENGELBRECHT, B. M. J., COMITA, L. S., CONDIT, R., KURSAR, T. A., TYREE, M. T., TURNER, B. L. \& HUBBELL, S. P. 2007. Drought sensitivity shapes species distribution patterns in tropical forests. Nature 447: 80-82. DOI: 10.1038/nature05747.

GOVAERTS, R. H. A., SIMPSON, D. A., BRUHL, J. J., EGOROVA, T., GOETGHEBEUR, P. \& WILSON, K. L. 2007. World Checklist of Cyperaceae. Sedges. Kew Publishing.

GOYETTE, B., PICHE, M., BROWNBRIDGE, M. \& McGRATH, D. 2014. Impact of handling practices on the quality of bare-root plants: A review. Journal of Environment Horticulture 32 (2): 103-113.

JACKSON, D. P., ENEBAK, S. A. \& SOUTH, D. B. 2012. Survival of southern pine seedlings after inoculations with Pythium and cold storage in the presence of peat moss. Forest Pathology 42: 44-51.

LIU, H., REN, H., LIU, Q., WEN, X., MAUNDER, M. \& GAO, J. 2015. Translocation of threatened plants as a conservation measure in China. Conservation Biology 29(6): 1537-1551. DOI: $10.1111 /$ cobi.12585.

MEEKIONG, K., SHABDIN, Z., IPOR, I. B. \& AMPENG, A. 2011. Notes on the genus Mapania (Cyperaceae) from Lanjak Entimau. In: MOHAMED, H., IPOR, I. B., MEEKIONG, K., SAPUAN, A. \& AMPENG, A. (Eds.). Lanjak Entimau Wildlife Sanctuary, 'Hidden Jewel of Sarawak', Academy of Science Malaysia and Sarawak Forest Department. Pp. 105-110.

MIRAADILA, M. I., SHABDIN, Z. \& MEEKIONG, K. 2015. Preliminary report on the distribution of genus Mapania (Cyperaceae) in Sarawak. International Conference on Biodiversity and Conservation, 26-28 May 2015, Sultan Idris Education University. Pp. 264-272.

MIRAADILA, M. I., SHABDIN, Z. \& MEEKIONG, K. 2016a. Two new species and one new geographical record for Sarawak, Malaysia (Cyperaceae; Mapanioideae). Reinwardtia 15(2): 129-135.

MIRAADILA, M. I. \& SHABDIN, Z. 2016b. Mapania meekiongii, a new species of Mapania (Cyperaceae) from Sarawak, Malaysia. Folia Malaysiana 17(1): 61-66.
MIRAADILA, M. I. 2018. Systematic Study of Genus Mapania Aublet (Cyperaceae) in Sarawak. Universiti Malaysia Sarawak, Malaysia. [MSc. Thesis].

MUASYA, A. M., SIMPSON, D. A., VERBOOM, G. A., GOETGHEBEUR, P., NACZI, R. F. C., CHASE, M. W. \& SMETS, E. 2009. Phylogeny of Cyperaceae based on DNA sequence data: Current Progress and Future Prospects. Botanical Review 75: 2-21.

NACZI, R. F. C. \& FORD, B. A. 2008. Sedges: Uses, Diversity and Systematics of the Cyperaceae. Missouri Botanical Garden Press, U.S.A.

NEGBI, M. 1992. A sweetmeat plant, a perfume plant and their weedy relatives: A chapter in the history of Cyperus esculentus L. and Cyperus rotundus L. Economic Botany 46: 64-71.

SHABDIN, Z., CULHAM, A., SIMPSON, D. A. \& MEEKIONG, K. 2013a. Mapania sapuaniana (Cyperaceae), a new sedge species from Sarawak. Blumea 58: 45-48.

SHABDIN, Z., CULHAM, A., SIMPSON, D. A. \& MEEKIONG, K. 2013b. Mapania multiflora, a distinctive new species of Cyperaceae (Mapanioideae) from Borneo. Kew Bulletin 68: 673-678.

SHABDIN, Z., MEEKIONG, K. \& MIRAADILA, M. I. 2016. A new Mapania species (Cyperaceae) from Sarawak, Malaysia. Borneo Journal of Resource Science and Technology 6(1): 19-24.

SIMPSON, D. A. 1992. A Revision of the Genus Mapania. Surrey, Royal Botanic Gardens, Kew.

SIMPSON, D. A. \& INGLIS, C. A. 2001. Cyperaceae of economic, ethnobotanical and horticultural importance: a checklist. Kew Bulletin 56: 257-360.

SIMPSON, D. A., FURNESS, C. A., HODKINSON, T. R., MUASYA, A. M. \& CHASE, M. W. 2003. Phylogenetic relationships in Cyperaceae subfamily Mapanioideae inferred from pollen and plastid DNA sequence data. American Journal of Botany 90(7): 1071-1086.

SIMPSON, D. A., YESSON, C., CULHAM, A., COUCH, C. A. \& MUASYA, A. M. 2011. Climate Change and Cyperaceae. In: HODKINSON, T. R., JONES, M. B., WALDREN, S. \& PARNELL, J. A. N. (Eds.) Climate Change, Ecology and Systematics. Cambridge University Press. 